\title{
Surface Fatigue Life of CBN and Vitreous Ground Carburized and Hardened AISI 9310 Spur Gears
}

Dennis P. Townsend

Lewis Research Center

Cleveland, Ohio

and

P.R. Patel

Bell Helicopter Textron

Fort Worth, Texas

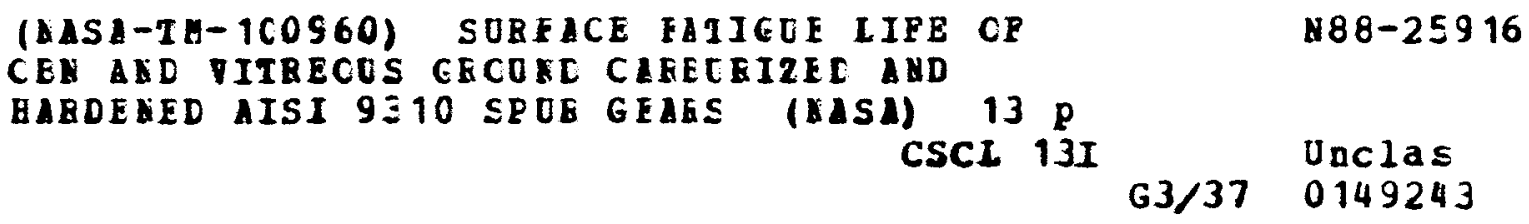

Prepared for the

International Off Highway and Powerplant Congress and Exposition sponsored by the Society of Automatic Engineers

Milwaukee, Wisconsin, September 12-15, 1988 


\title{
SURFACE FATIGUE LIFE OF CBN AND VITREOUS GROUND CARBURIZED
}

\author{
AND HARDENED AISI 9310 SPUR GEARS \\ Dennis P. Townsend \\ National Aeronautics and Space Administration \\ Lewis Research Center \\ Cleveland, Ohio 44135 \\ and \\ P.R. Patel \\ Bell Helicopter Textron \\ Fort Worth, Texas 76101
}

\section{ABSTRACT}

Spur gear surface endurance tests were conducted to investigate CBN ground AISI 9310 spur gears for use in aircraft applications, to determine their endurance characteristics and to compare the results with the endurance of standard vitreous ground AISI 9310 spur gears. Tests were conducted with VIM-VAR AISI 9310 carburized and hardened gears that were finish ground with either CBN or vitreous grinding methods. Test conditions were an inlet oil temperature of $320 \mathrm{~K}$ $\left(116^{\circ} \mathrm{F}\right)$, an outlet oil temperature of $350 \mathrm{~K}$ $\left(170^{\circ} \mathrm{F}\right)$, a maximum Hertz stress of $1.71 \mathrm{GPa}$ (248 ksi), and a speed of $10000 \mathrm{rpm}$. The CBN ground gears exhibited a surface fatigue life that was slightly better than the vitreous ground gears. The subsurface residual stress of the CBN ground gears was approximately the same as that for the standard vitreous ground gears for the $C B N$ grinding method used.

GRINDING OF CARBURIZED AND HARDENED GEAR TEETH for aircraft application has been standard practice for many years. Grinding is required to produce the required accuracy and surface finish necessary for improved life, reduced noise and dynamic loads for aircraft gears. Until a few years ago, the method used for grinding hardened gears was the standard vitreous grinding wheels. The vitreous grinding method typically produces a very shallow compressive stress $(<0.013 \mathrm{~mm}$ $(0.0005$ in. )) on the surface of the ground part but has very little effect on the subsurface compressive residual stress.

A few years ago the cubic boron nitride ( $C B N$ ) grinding wheels were introduced for grinding gears and other parts ( 1 . ${ }^{\star}$ The CBN grinding wheel allows a much greater rate of

* Numbers in parentheses designate references at end of paper. stock removal of hardened parts without producing grinding burns that are prevalent with vitreous grinding. The $C B N$ crystals have a high thermal conductivity compared to the vitreous material and conducts the heat away from the part instead of into the part. In addition, the CBN crystals are very sharp and very hard and produce a chip-like cutting action. When a hardened gear or other part is ground very hard with considerable force, a subsurface residual compressive stress is developed below the surface (2). This subsurface residual compressive stress has been shown to improve the subsurface fatigue life of gears and bearings $(3,4)$. The CBN grinding of carburized and hardened AISI 9310 steel spur gears should, therefore, produce equivalent or improved surface fatigue life.

The objectives of the research reported herein were: (1) to investigate $C B N$ grinding as a method for finishing aircraft-type gears, (2) to determine the surface endurance characteristics of CBN ground carburized and hardened AISI 9310 steel spur gears, and (3) to compare the results with standard vitreous ground carburized and hardened AISI 9310 steel spur gears. To accomplish these objectives, tests were conducted with two groups of gears manufactured from one lot of material. One group of spur gears from that lot were CBN ground. For comparison purposes, the other group of spur gears were manufactured by vitreous grinding. The gear pitch diameter was $8.89 \mathrm{~cm}$ ( $3.50 \mathrm{in.})$ and 3.2 module (8 diametrial pitch). Test conditions included an oil inlet temperature of $320 \mathrm{~K}\left(116^{\circ} \mathrm{F}\right)$ that resulted in an oil outlet temperature of $350 \mathrm{~K}$ $\left(170^{\circ} \mathrm{F}\right)$, a maximum Hertz stress of $1.71 \mathrm{GPa}$ (248 ksi), and a shaft speed of $10000 \mathrm{rpm}$. APPARATUS AND PROCEDURES

GEAR TEST APPARATUS - The gear fatigue tests were performed in the NASA Lewis Research Center's gear fatigue test apparatus (Fig. 1). This test rig uses the four-square principle of applying the test gear load so that the input drive only needs to overcome the frictional losses in the system. 
A schematic of the test rig is shown in Fig. 1(b). Oil pressure and leakage flow are supplied to the load vanes through a shaft seal. As the oil pressure is increased on the load vanes inside the slave gear, torque is applied to the shaft. This torque is transmitted through the test gears back to the slave gear where an equal but opposite torque is maintained by the oil pressure. This torque on the test gears, which depends on the hydraulic pressure applied to the load vanes, loads the gear teeth to the desired stress leve1. The two identical test gears can be started under no load, and the load can be applied gradually without changing the running track on the gear teeth.

Separate lubrication systems are provided for the test gears and the main gearbox. The two lubricant systems are separated at the gearbox shafts by pressurized labyrinth seals. Nitrogen is the seal gas. The test gear lubricant is filtered through a $5 \mathrm{\mu m}$ nominal fiberglass filter. The test lubricant can be heated electrically with an immersion heater. The skin temperature of the heater is controlled to prevent overheating the test lubricant.

A vibration transducer mounted on the gearbox is used to automatically shut off the test $r i g$ when a gear surface fatigue occurs. The gearbox is also automatically shut of $f$ if there is a loss of oil flow to either the main gearbox or the test gears, if the test gear oil overheats, or if there is a loss of seal gas pressurization.

The belt-driven test rig can be operated at several fixed speeds by changing pulleys. The operating speed for the tests reported herein was $10000 \mathrm{rpm}$.

TEST GEARS - A photograph of the test gears is shown in Fig. 2. The dimensions of the gears are given in Table I. All gears had a nominal surface finish on the tooth face of $0.2 \mu \mathrm{m}$ ( 8 pin.) rms or better. Typical surface finish charts for both grinding methods are shown in Fig. 3. All gears have a standard $20^{\circ}$ involute profile with tip relief. The tip relief was $0.0013 \mathrm{~cm}(0.0005 \mathrm{in.})$ starting at the highest point of single tooth contact. One group of gears was ground with a vitreous grinding wheel with speed, feed and metal removal rate as shown in Table II. The second group of gears were ground with a CBN form grinder with speed, feed and metal removal rate as shown in Table II.

Residual stress profiles were established, using a gear configuration described in Table III, to determine the difference between the two grinding techniques. For baseline condition, one gear was tested in as-carburized condition. The stress measurements were made using $x$-ray diffraction technique at the approximate pitch diameter of the gears. The results of residual stress measurements are summarized in Fig. 4.

TEST MATERIAL - The gears were manufactured from vacuum induction melted, vacuum arc remelted (VIM VAR) AISI 9310 steel. The nominal chemical composition of the gears is given in Table IV. The heat treatment procedure for the test gears is given in Table $V$. The case and core proper- ties of the test gears are given in Table VI. Photomicrographs of the case and core of a test gear is given in Figs. $5(\mathrm{a})$ and (b).

TEST LUBRICANT - All the gears were lubricated with a single batch of synthetic paraffinic oil, which was the standard test lubricant for the gear tests. The physical properties of this lubricant are summarized in Table VII. Five percent of an extreme pressure additive, designated Lubrizol 5002 (partial chemical analysis given in Table VII) was added to the lubricant. TEST PROCEDURE - After the test gears were cleaned to remove their protective coating, they were assembled on the test rig. The test gears were run in an offset condition with a $0.30 \mathrm{~cm}$ (0.120 in.) tooth-surface overlap to give a surface load width on the gear face of $0.28 \mathrm{~cm}$ ( $0.110 \mathrm{in.})$, thereby allowing for an edge radius on the gear teeth. If both faces of the gears were tested, four fatigue tests could be run for each set of gears. All tests were run-in at a load per unit width of $1230 \mathrm{~N} / \mathrm{cm}$ (700 $\mathrm{lb} / \mathrm{in}$.) for $1 \mathrm{hr}$. The load was then increased to $5800 \mathrm{~N} / \mathrm{cm}$ ( $3300 \mathrm{lb} / \mathrm{in}$.$) , which resulted in a 1.71 \mathrm{GPa}$ ( $248 \mathrm{ksi}$ ) pitch-1ine maximum Hertz stress. At the pitchline load the tooth bending stress was $0.21 \mathrm{GPa}$ ( $30 \mathrm{ksi}$ ) if plain bending was assumed. However, because there was an offset load, there was an additional stress imposed on the tooth bending stress. Combining the bending and torsional moments gave a maximum stress of $0.26 \mathrm{GPa}$ ( $37 \mathrm{ksi})$. This bending stress did not include the effects of tip relief which would also increase the bending stress.

Since the offset test method may introduce edge loading effects the method was originally checked with and without crowned gears. There was no difference between crowned and uncrowned gears, also all fatigue spalls with uncrowned gears originate evenly along the tooth flank and never start at the edge location. This is proof that the offset test condition is an acceptable method for surface fatigue testing.

Operating the test gears at $10000 \mathrm{rpm}$ gave a pitchline velocity of $46.55 \mathrm{~m} / \mathrm{sec}$ ( $9163 \mathrm{ft} / \mathrm{min}$ ). Lubricant was supplied to the inlet mesh at $800 \mathrm{~cm}^{3} / \mathrm{min}(49 \mathrm{in} .3 / \mathrm{min})$ and $320 \pm 6 \mathrm{~K}\left(116 \pm 10^{\circ} \mathrm{F}\right)$. The lubricant outlet temperature was nearly constant at $350 \pm 3 \mathrm{~K}\left(170 \pm 5^{\circ} \mathrm{F}\right)$. The tests ran continuously ( $24 \mathrm{hr} / \mathrm{day})$ until the rig was automatically shut down by the vibration detection transducer (located on the gearbox adjacent to the test gears) or until $500 \mathrm{hr}$ of operation without failure were completed. The lubricant circulated through $5 \mu \mathrm{m}$ fiberglass filter to remove wear particles. For each test, 3.8 1iter ( $1 \mathrm{gal}$ ) of lubricant were used. At the end of each test, the lubricant and filter element were discarded. Inlet and outlet oil temperatures were continuously recorded on a strip-chart recorder.

The pitchline elastohydrodynamic (EHD) film thickness was calculated by the method of Ref. 5 . It was assumed, for this film thickness calculation, that the gear surface temperature at the pitchline was equal to the outlet oil temperature and that the inlet oil temperature to the contact 
even though the oil jet inlet temperature was considerably lower. It is possible that the gear surface temperature was even higher than the oil outlet temperature, especially at the end points of sliding contact. The EHD film thickness for these conditions was computed to be $0.33 \mu \mathrm{m}$ (13 $\mu$ in.), which gave an initial ratio of $\mathrm{film}$ thickness to composite surface roughness $(\mathrm{h} / \mathrm{s})$ of 1.15 at the $1.71 \mathrm{GPa}$ ( $248 \mathrm{ksi}$ ) pitchlines maximum Hertz stress.

Each pair of gears was considered as a system and, hence, a single test. Test results were evaluated using Weibull plots calculated by the method of Johnson (6). (A Weibull plot is the number of stress cycles versus the statistical percent of gear system failed.)

RESULTS AND DISCUSSION

One lot of VIM VAR AISI 9310 steel spur gears was divided into two groups and endurance tested. One group was ground by a vitreous grinding wheel, while the second group was ground by a $C B N$ form grinding wheel. Test conditions consisted of a tangential tooth 1 oad of $5800 \mathrm{~N} / \mathrm{cm}$ (3300 1b/in.), which produced a maximum Hertz stress of $1.7 \mathrm{GPa}(248 \mathrm{ksi})$, and a speed of $10000 \mathrm{rpm}$. The gears failed by classical subsurface pitting fatigue. The pitting fatigue life results of these tests are shown in the Weibull plots of Fig. 6 and are summarized in Table VIII. Pitting fatigue life results for the gears that were ground by the vitreous grinding wheel are shown in Fig. 6(a). The 10 and 50 percent lines were $82.5 \times 10^{6}$ and $371 \times 10^{6}$ stress cycles (157 and $618 \mathrm{hr}$ ), respectively, the Weibull slope was 1.25 . The failure index (i.e., the number of fatigue failures out of the number of sets tested) was 6 out of 16 . A typical fatigue spall that occurs near the pitchline is shown in Fig. 7 . This is a typical fatigue spall similar to those observed in rolling element fatigue tests. The pitchline pitting is the result of a high subsurface shearing stress which develops subsurface cracks. These subsurface cracks propagate into a crack network which results in a fatigue spall that is slightly below the pitchline where the sliding condition is more severe.

Pitting fatigue life results for the gear systems that were ground by a CBN form grinder are shown in Fig. 6(b). The 10 and 50 percent surface fatigue 1 ines were $122.7 \times 10^{6}$ and $502 \times 10^{6}$ stress cycles (205 and $837 \mathrm{hr}$ ), respectively, the Weibull slope was 1.34. The failure index was 7 out of 18 . The 10 percent surface fatigue life of the CBN ground gears was $\sim 1-1 / 2$ times that of the standard vitreous ground gears. The confidence number was 60 percent, which indicates that there are 600 chances out of 1000 tests that the 10 percent life of the CBN ground gears will be superior to the 10 percent life of the vitreous ground gears. This indicates that there is not a lot of statistical significance to the life difference between the two groups of gears. However, it does indicate that the $C B N$ gears are at least equivalent in life to the vitreous ground gears or slightly better. The equivalent residual stress profiles of the two methods of grinding would also indicate that the fatigue life should be approximately the same. A more vigorous $\mathrm{CBN}$ grinding could induce some additicnal compressive residual stress; thereby, improving the surface fatigue life, Refs. 2 and 3 . A summary of the fatigue lives of the two groups of ground gears are given in Fig. 6(c).

\section{SUMMARY OF RESULTS}

Spur gear endurance tests were conducted to investigate CBN ground AISI 9310 spur gears for use in aircraft gear applications, to determine their endurance characteristics and to compare the results with the endurance of standard vitreous ground AISI 9310 spur gears. Tests were conducted with VIM-VAR AISI 9310 carburized and hardened gears that were finish ground with either $C B N$ or vitreous grinding methods. Test conditions were an inlet oil temperature of $320 \mathrm{~K}\left(116^{\circ} \mathrm{F}\right)$, an outlet oil temperature of $350 \mathrm{~K}\left(170^{\circ} \mathrm{F}\right)$, a maximum Hertz stress of $1.71 \mathrm{GPa}$ (248 ksi), and a speed of $10000 \mathrm{rpm}$. The following results were obtained:

1. The CBN ground gears exhibited a surface fatigue life that was slightly better than the vitreous ground gears.

2. The subsurface residual stress of the $C B N$ ground gears was approximately the same as that for the standard vitreous ground gears for the CBN grinding method used.

REFERENCES

1. R.C., DeVries, "Cubic Boron Nitride: Handbook of Properties," REPT-72CRD178, General Electric Co., Schenectady, NY, June 1972. (Avail. NTIS, AD-907330L).

2. G.J., Kimmet, "CBN Finish Grinding of Hardened Spiral Bevel and Hypoid Gears," AGMA Paper 84FTM6, American Gear Manufacturers Association, Alexandria, VA, Oct. 1984.

3. G.A. Johnson, and E. Ratterman, "Enhanced Product Performance Through CBN Gringing Gear Technology, Vo1. 5, No. 5, Sept/Oct 1988.

4. H.H., Coe, and E.Z., Zaretsky, "Effect of Interference Fits on Roller Bearing Fatigue Life," ASLE Trans., vol. 30, no. 2, Apr. 1987, pp. 131-140.

5. D., Dowson, and G.R., Higginson, "Elastohydrodynamic Lubrication, The Fundamental of Roller and Gear Lubrication," New York: Pergamon Press, 1966.

6. L.G., Johnson, "The Statistical Treatment of Fatigue Experiments," New York: Elsevier Publication Co., 1964. 
TABLE I. - GEAR DATA

[Gear tolerance per AGMA class 12.]

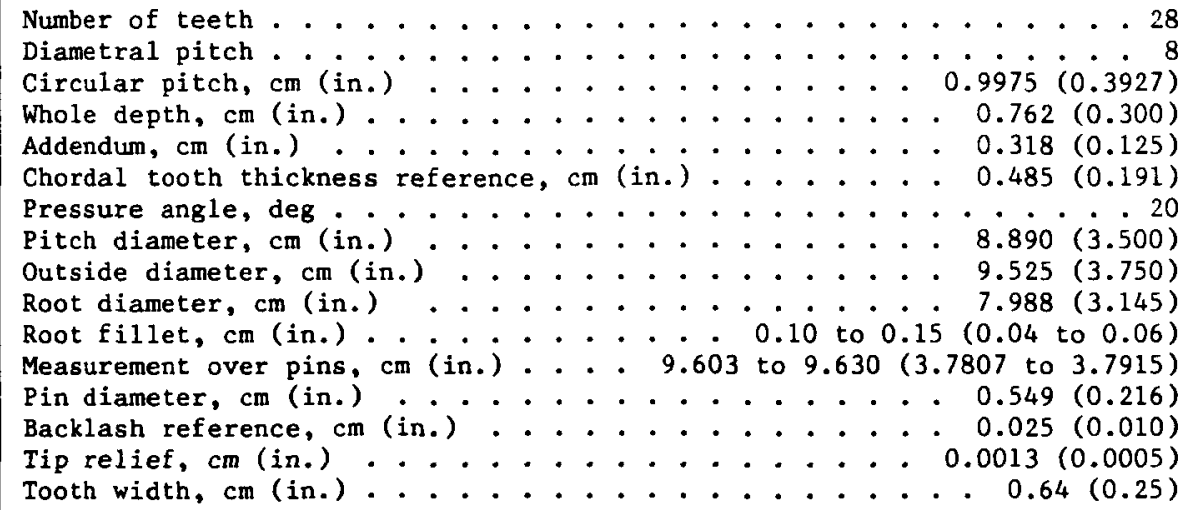

TABLE II. - GRINDING DATA FOR VITREOUS AND CBN GROUND SPUR GEARS

\begin{tabular}{|l|c|c|c|c|c|c|c|}
\hline & $\begin{array}{c}\text { Wheel } \\
\text { speed, } \\
\text { rpm }\end{array}$ & $\begin{array}{c}\text { Grit } \\
\text { size }\end{array}$ & $\begin{array}{c}\text { Finish } \\
\mu m(\mu i n .)\end{array}$ & $\begin{array}{c}\text { Table } \\
\text { speed, } \\
\text { sec/pass }\end{array}$ & $\begin{array}{c}\text { Number } \\
\text { of passes } \\
\text { per tooth }\end{array}$ & $\begin{array}{c}\text { Depth of } \\
\text { cut per } \\
\text { pass }\end{array}$ & $\begin{array}{c}\text { Time } \\
\text { to grind } \\
\text { one gear }\end{array}$ \\
\hline Vitreous & 1600 & 60 & $0.36(14)$ & 2 & 36 & $\begin{array}{c}0.018 \mathrm{~mm} \\
(0.0007 \mathrm{in.})\end{array}$ & $15 \mathrm{hr}$ \\
CBN & 3400 & 70 & $0.30(12)$ & 6 & 5 & $\begin{array}{c}0.13 \mathrm{~mm} \\
(0.005 \mathrm{in.})\end{array}$ & $20 \mathrm{~min}$ \\
\hline
\end{tabular}

TABLE III. - DATA FOR GEAR USED FOR

RESIDUAL STRESS MEASUREMENTS

\begin{tabular}{|c|c|}
\hline $\begin{array}{l}\text { Number of teeth } . . \\
\text { Diametral pitch } \\
\text { Pressure angle, deg } . . \\
\text { Pitch diameter, } \mathrm{cm}(\text { in.) } \\
\text { Face width, } \mathrm{cm}(\text { in.). }\end{array}$ & 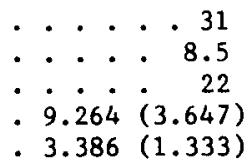 \\
\hline
\end{tabular}


TABLE IV. - CHEMICAL

COMPOSITION OF TEST

MATERIALS BY

PERCENT WEIGHT

\begin{tabular}{|l|c|}
\hline \multicolumn{1}{|c|}{ Element } & $\begin{array}{l}\text { AISI } \\
9310 \\
\text { gears }\end{array}$ \\
\hline Carbon (core) & 0.10 \\
Manganese & .60 \\
Phosphorus & .006 \\
Sulfur & .005 \\
Silicon & .24 \\
Copper & .04 \\
Chromium & 1.35 \\
Molybdenum & .16 \\
Vanadium & .01 \\
Nickel & 3.37 \\
Iron & Balance \\
\hline
\end{tabular}

TABLE v. - HEAT TREAT PROCEDURE FOR TEST GEARS

\begin{tabular}{|c|c|}
\hline \multicolumn{2}{|c|}{ Pre-carburize heat treatment } \\
\hline $\begin{array}{l}\text { Normalize } \\
\text { Harden } \\
\text { Temper } \\
\text { Carburize }\end{array}$ & $\begin{array}{c}1725^{\circ} \mathrm{F} \text { for } 1 \mathrm{hr} \\
\text { Air cool } \\
1500^{\circ} \mathrm{F} \text { for } 1 \mathrm{hr} \\
01^{\circ} \text { quench } \\
1000^{\circ} \mathrm{F} \text { for } 4 \mathrm{hr} \\
1700^{\circ} \mathrm{F} \text { for } 6.5 \mathrm{hr} \\
1.0 \text { percent carbon potential }\end{array}$ \\
\hline \multicolumn{2}{|c|}{ Post-carburize heat treatment } \\
\hline $\begin{array}{l}\text { Sub-critical anneal } \\
\text { Harden } \\
\text { Sub-zero treat } \\
\text { Temper }\end{array}$ & $\begin{array}{l}1150^{\circ} \mathrm{F} \text { for } 2 \mathrm{hr} \\
\text { Air cool } \\
1500^{\circ} \mathrm{F} \text { for } 1 \mathrm{hr} \\
0{ }^{\circ} \text { quench } \\
-115^{\circ} \mathrm{F} \text { for } 4 \mathrm{hr} \\
300^{\circ} \mathrm{F} \text { for } 4 \mathrm{hr} \\
\text { Air cool }\end{array}$ \\
\hline
\end{tabular}

TABLE VI. - CASE AND CORE PROPERTIES OF TEST GEARS

\begin{tabular}{|l|r|r|}
\hline & Conv. Ground & \multicolumn{1}{|c|}{ CBN Ground } \\
\hline Surface hardness, HRC & 61.5 & 63.0 \\
HRC 60 depth, mm (in.) & $0.45(0.018)$ & $0.53(0.021)$ \\
HRC 50 depth, mm (in.) & $0.99(0.039)$ & $0.97(0.038)$ \\
Core hardness, HRC & 38.0 & 38.0 \\
Retained austenite, percent & 6.0 & 6.6 \\
\hline
\end{tabular}


TABLE VII. - LUBRICANT PROPERTIES

\begin{tabular}{|c|c|}
\hline Property & $\begin{array}{l}\text { Synthetic } \\
\text { paraffinic oil } \\
\text { plus additives }\end{array}$ \\
\hline $\begin{array}{l}\text { Kinematic viscosity, } \mathrm{cm}^{2} / \mathrm{sec}(\mathrm{c}) \text { at: } \\
244 \mathrm{~K}\left(-20^{\circ} \mathrm{F}\right) \\
311 \mathrm{~K}\left(100^{\circ} \mathrm{F}\right) \\
372 \mathrm{~K}\left(210^{\circ} \mathrm{F}\right) \\
477 \mathrm{~K}\left(400^{\circ} \mathrm{F}\right) \\
\text { Flash point, } \mathrm{K}\left({ }^{\circ} \mathrm{F}\right) \\
\text { Fire point, } \mathrm{K}\left({ }^{\circ} \mathrm{F}\right) \\
\text { Pour point, } \mathrm{K}\left({ }^{\circ} \mathrm{F}\right) \\
\text { Specific gravity } \\
\text { Vapor pressure at } 311 \mathrm{~K}\left(100^{\circ} \mathrm{F}\right) \text {, } \\
\text { me Hg (or torr) } \\
\text { Specific heat at } 311 \mathrm{~K}\left(100^{\circ} \mathrm{F}\right) \text {, } \\
\mathrm{J} /(\mathrm{kg})(\mathrm{K}) ;\left(\mathrm{Btu} /(1 \mathrm{~b})\left({ }^{\circ} \mathrm{F}\right)\right)\end{array}$ & $\begin{array}{rr}2500 \times 10^{-2} & (2500) \\
31.6 \times 10^{-2} & (31.6) \\
5.5 \times 10^{-2} & (5.5) \\
2.0 \times 10^{-2} & (2.0) \\
508 & (455) \\
533 & (500) \\
219 & (-65) \\
0.8285 \\
0.1\end{array}$ \\
\hline
\end{tabular}

TABLE VIII. - SPUR GEAR FATIGUE LIFE RESULTS

(Pitch diameter, $8.89 \mathrm{~cm}$ (3.50 in.); maximum Hertz stress, $1.71 \mathrm{GPa}$ ( $248 \mathrm{ksi}$ ); speed, $10000 \mathrm{rpm}$; lubricant, synthetic paraffinic oil; gear temperature, $\left.350 \mathrm{~K}\left(170^{\circ} \mathrm{F}\right).\right]$

\begin{tabular}{|c|c|c|c|c|c|}
\hline \multirow[t]{2}{*}{ Material } & \multicolumn{2}{|c|}{$\begin{array}{c}\text { Gear system life, } \\
\text { revolutions }\end{array}$} & \multirow[t]{2}{*}{$\begin{array}{l}\text { Weibull } \\
\text { slope }\end{array}$} & \multirow[t]{2}{*}{$\begin{array}{l}\text { Failure } \\
\text { index }\end{array}$} & \multirow{2}{*}{$\begin{array}{l}\text { Confidence } \\
\text { number at } \\
\text { 10-percent } \\
\text { levelb }\end{array}$} \\
\hline & $\begin{array}{l}\text { 10-percent } \\
\text { life }\end{array}$ & $\begin{array}{l}\text { 50-percent } \\
\text { life }\end{array}$ & & & \\
\hline $\begin{array}{l}\text { Standard } \\
\text { ground } \\
\text { VIM-VAR } \\
\text { AISI } 9310\end{array}$ & $82.5 \times 10^{6}$ & $371 \times 10^{6}$ & 1.25 & 6 out of 16 & -- \\
\hline $\begin{array}{l}\text { CBW } \\
\text { ground } \\
\text { VIM-VAR } \\
\text { AISI } 9310\end{array}$ & $122.7 \times 10^{6}$ & $502 \times 1^{6}$ & 1.34 & 7 out of 18 & 60 \\
\hline
\end{tabular}

aNumber of surface fatigue failures out of number of gears tested.

bercentage of time that 10-percent life obtained with AISI 9310 gears will have the same relation to the 10-percent life obtained with EX-53 gears or CBS $1000 \mathrm{M}$. 


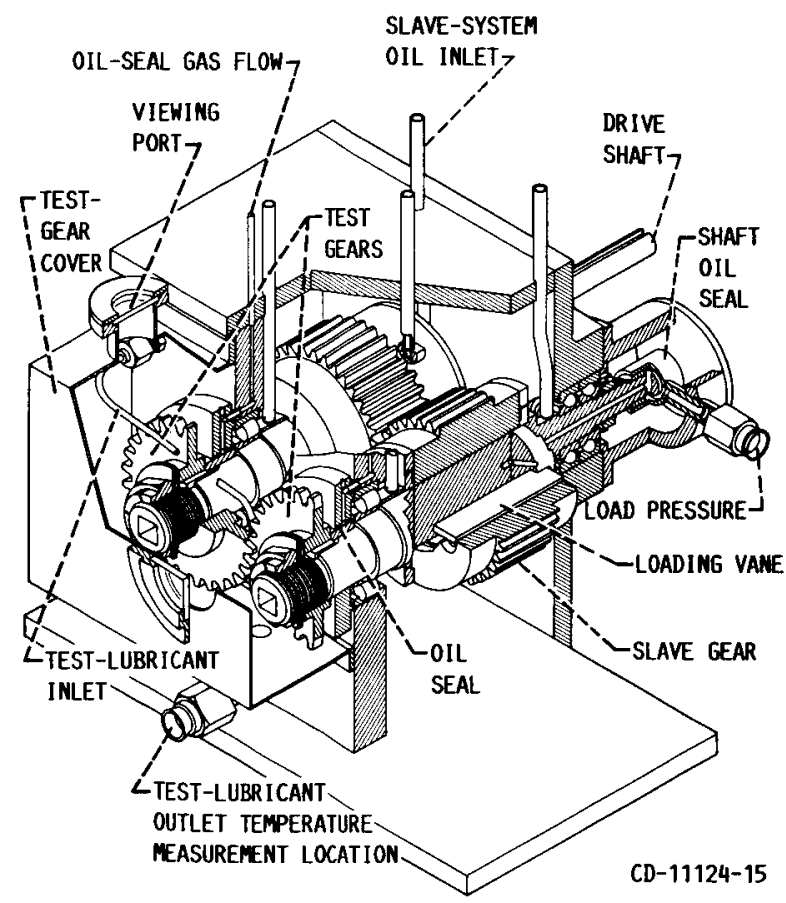

(A) CUTANAY VIEW.

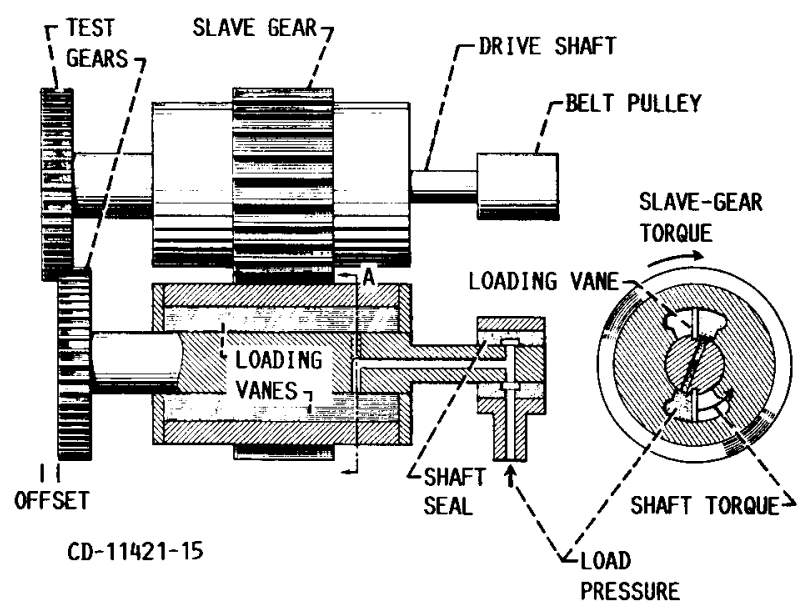

(B) SCHEMATIC DIAGRAM.

FIGURE 1. - NASA LEWIS RESEARCH CENTER'S GEAR FATIGUE TEST APPARATUS. 


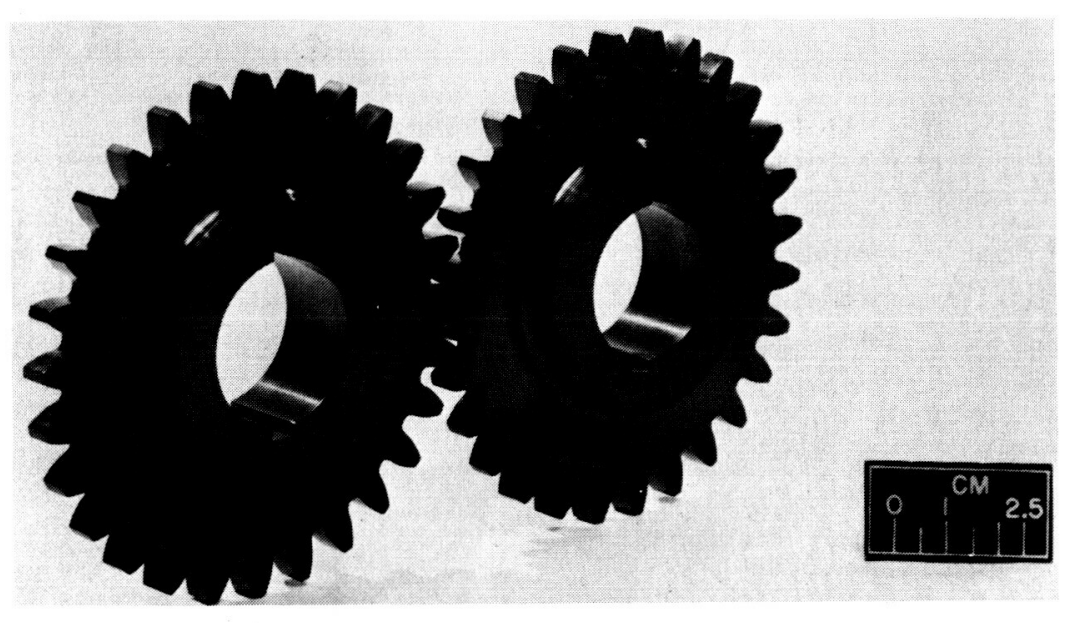

FIGURE 2. - TEST-GEAR CONFIGURATION.

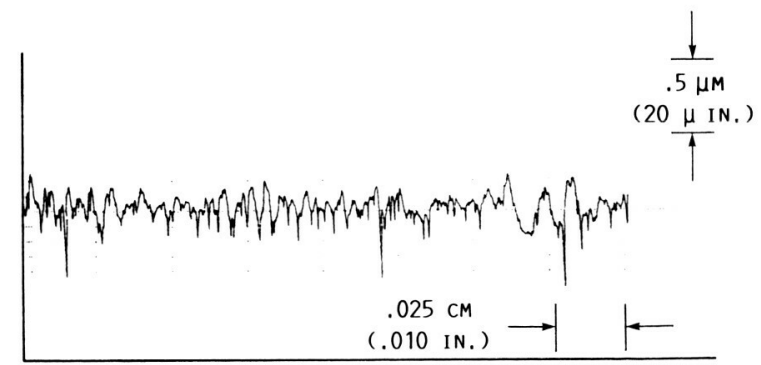

(A) CONVENTIONAL GROUND FINISH $0.134 \mu \mathrm{M}(5.26 \mu \mathrm{IN}$.) AA.

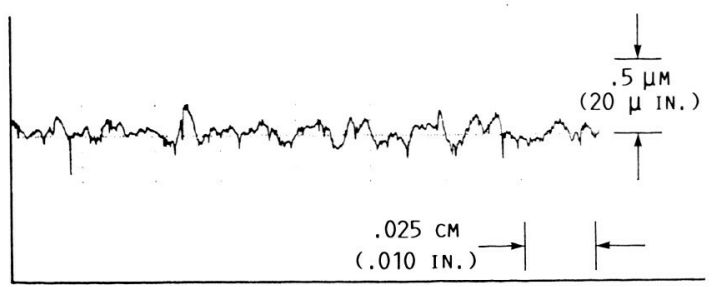

(B) CBN GROUND FINISH $0.091 \mu \mathrm{M}(3.60 \mu \mathrm{IN}$.) AA.

FIGURE 3. - SURFACE FINISH MEASUREMENT IN PROFILE DIRECTION WITH .010 CUTOFF.

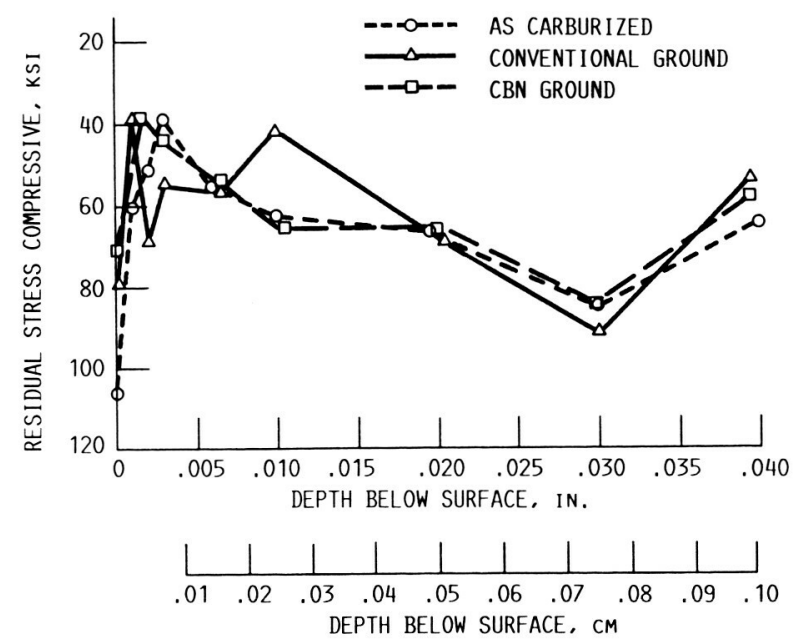

FIGURE 4. - RESIDUAL STRESS MEASUREMENTS ON TOOTH FLANK OF AISI 9310 SPUR GEARS GROUND BY VITREOUS AND CBN GRINDING WHEELS. 


\section{ORIGINAC PAGE IS \\ POR QUALITY.}

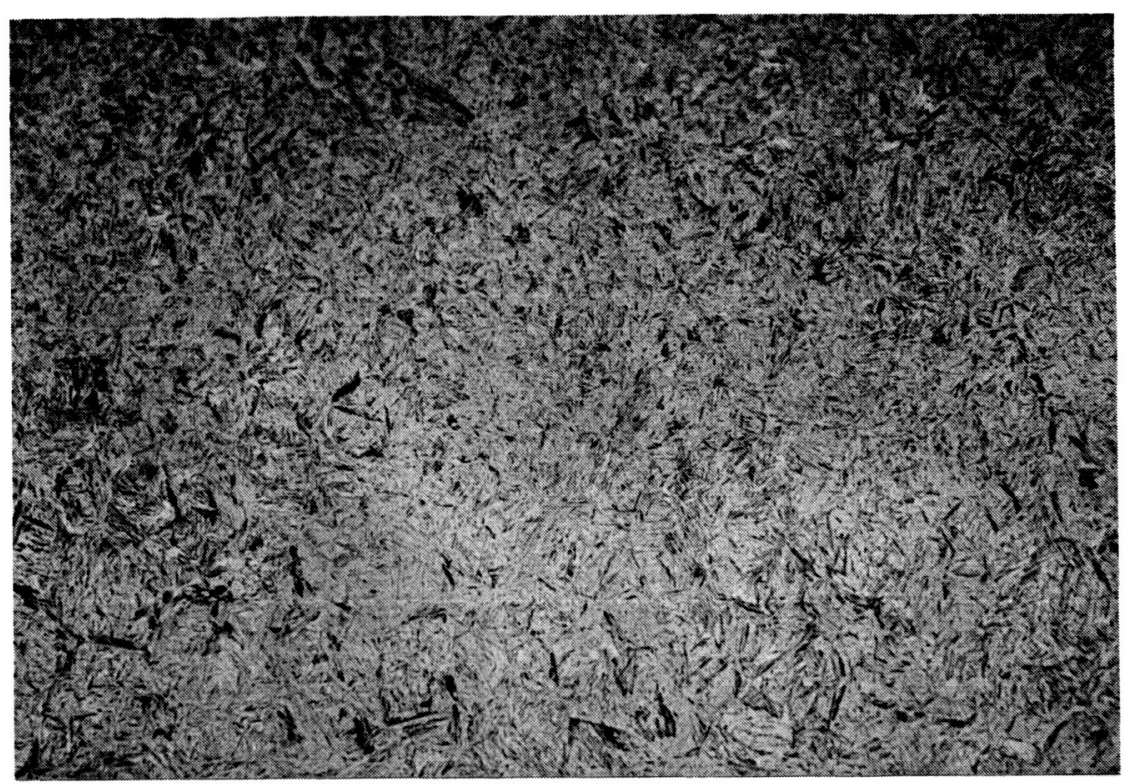

(A) CASE.

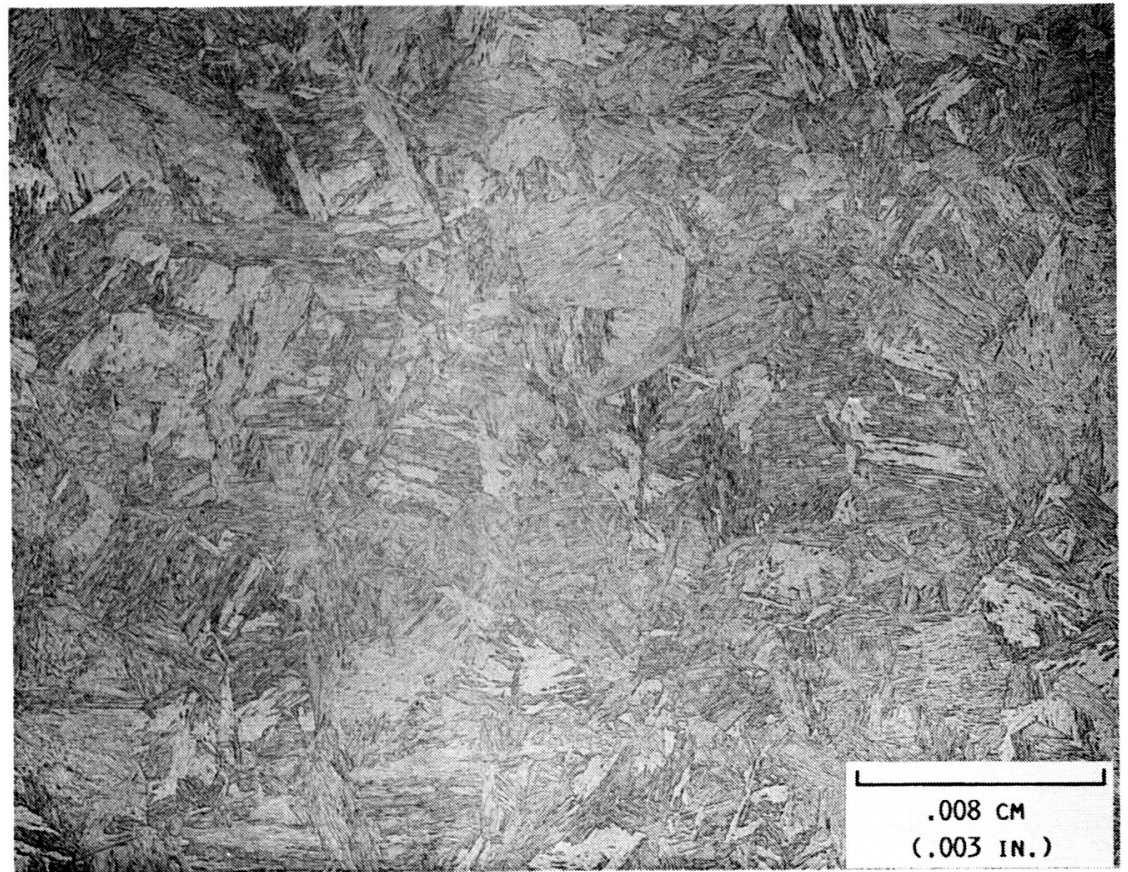

(B) CORE.

FIGURE 5. - PHOTOMICROGRAPHS OF THE CASE AND CORE MATERIAL FOR TEST GEARS. 

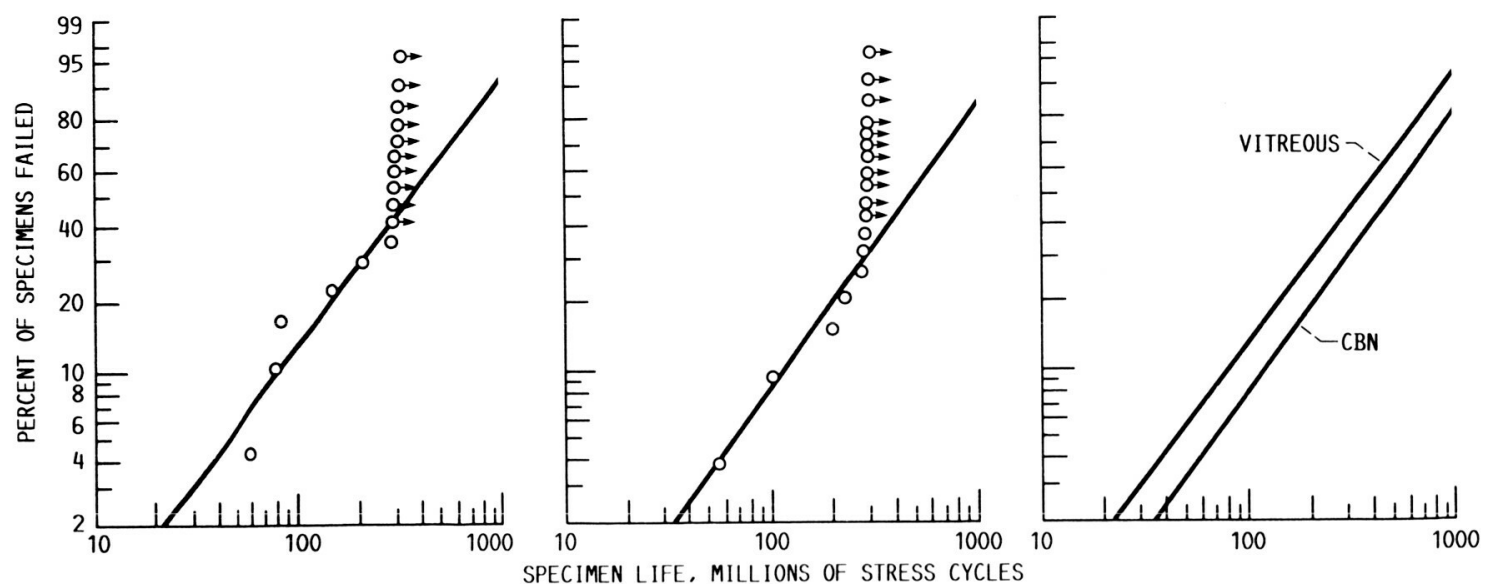

(A) VITREOUS GROUND.

(B) CBN GROUND.

(C) SUMMARY.

FIGURE 6. - SURFACE FATIGUE LIFE OF CARBURIZED, HARDENED, GROUND AND SHOT PEENED TEST GEARS. SPEED 10000 RPM; MAXIMUM HERTZ STRESS, $1.71 \mathrm{GPA}(248 \mathrm{KSI})$; TEMPERATURE, $350 \mathrm{~K}(170 \mathrm{~F})$ : LUBRICANT, SYNTHETIC PARAFFINIC WITH 5-PERCENT E P ADDITIVE.

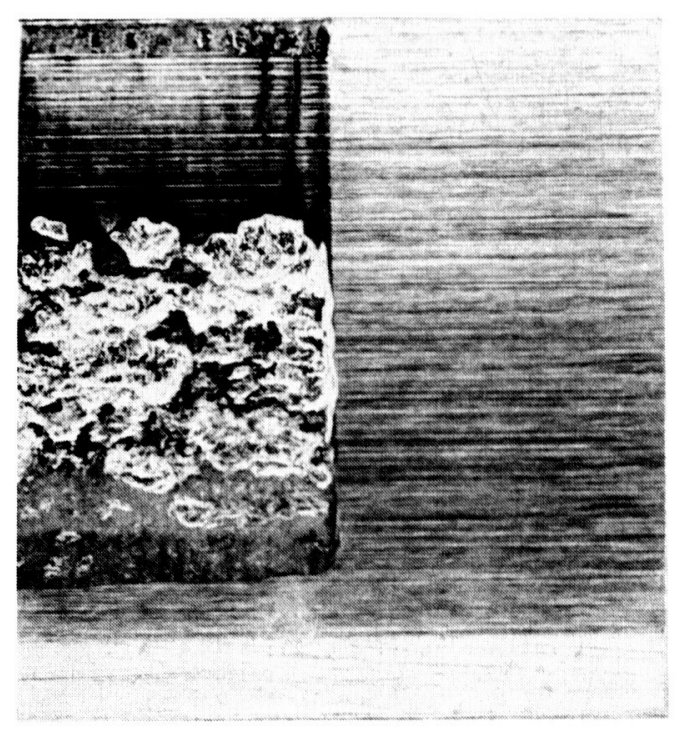

FIGURE 7. - TYPICAL FATIGUE SPALL FOR AISI 9310 GEARS. 


\begin{tabular}{|c|c|c|c|c|}
\hline \multicolumn{5}{|c|}{ Report Documentation Page } \\
\hline $\begin{array}{l}\text { 1. Report No. } \\
\begin{array}{l}\text { NASA TM-100960 } \\
\text { AVSCOM TR-88-C-019 }\end{array}\end{array}$ & \multicolumn{2}{|c|}{ 2. Government Accession No. } & \multicolumn{2}{|c|}{ 3. Recipient's Catalog No. } \\
\hline \multicolumn{3}{|c|}{ 4. Title and Subtitle } & \multicolumn{2}{|l|}{ 5. Report Date } \\
\hline \multicolumn{3}{|c|}{$\begin{array}{l}\text { Surface Fatigue Life of CBN and Vitreous Ground Carburized and } \\
\text { Hardened AISI } 9310 \text { Spur Gears }\end{array}$} & \multicolumn{2}{|c|}{ 6. Performing Organization Code } \\
\hline \multicolumn{3}{|l|}{$\begin{array}{l}\text { 7. Author(s) } \\
\text { Dennis P. Townsend and P.R. Patel }\end{array}$} & \multicolumn{2}{|c|}{$\begin{array}{l}\text { 8. Performing Organization Report No. } \\
\text { E-4185 }\end{array}$} \\
\hline & & & \\
\hline \multicolumn{3}{|l|}{ 9. Performing Organization Name and Address } & & \\
\hline \multicolumn{3}{|l|}{$\begin{array}{l}\text { NASA Lewis Research Center } \\
\text { Cleveland, Ohio } 44135-3191\end{array}$} & \multicolumn{2}{|c|}{$\begin{array}{l}\text { IL162209A47A } \\
505-63-51\end{array}$} \\
\hline \multirow{2}{*}{\multicolumn{3}{|c|}{$\begin{array}{l}\text { and } \\
\text { Propulsion Directorate } \\
\text { U.S. Army Aviation Research and Technology Activity-AVSCOM } \\
\text { Cleveland, Ohio } 44135-3127\end{array}$}} & \multicolumn{2}{|c|}{ 11. Contract or Grant No. } \\
\hline & & & \multirow{2}{*}{\multicolumn{2}{|c|}{$\begin{array}{l}\text { 13. Type of Report and Period Covered } \\
\text { Technical Memorandum }\end{array}$}} \\
\hline \multirow{2}{*}{\multicolumn{3}{|c|}{$\begin{array}{l}\text { 12. Sponsoring Agency Name and Address } \\
\text { National Aeronautics and Space Administration } \\
\text { Washington, D.C. 20546-0001 } \\
\text { and } \\
\text { U.S. Army Aviation Systems Command } \\
\text { St. Louis, Mo. 63120-1798 }\end{array}$}} & & \\
\hline & & & \multicolumn{2}{|c|}{ 14. Sponsoring Agency Code } \\
\hline \multicolumn{5}{|c|}{$\begin{array}{l}\text { Prepared for the International Off Highway and Powerplant Congress and Exposition sponsored by the Society of } \\
\text { Automotive Engineers, Milwaukee, Wisconsin, September 12-15, 1988. Dennis P. Townsend, NASA Lewis } \\
\text { Research Center; P.R. Patel, Bell Helicopter Textron, Fort Worth, Texas 76101. }\end{array}$} \\
\hline \multicolumn{5}{|l|}{$\begin{array}{l}\text { 16. Abstract } \\
\text { Spur gear surface endurance tests wer } \\
\text { aircraft applications, to determine the } \\
\text { standard vitreous ground AISI } 9310 \mathrm{~s} \\
\text { hardened gears that were finish groun } \\
\text { inlet oil temperature of } 320 \mathrm{~K}\left(116^{\circ}\right. \\
1.71 \mathrm{GPa}(248 \mathrm{ksi}) \text {, and a speed of } 1 \\
\text { slightly better than the vitreous groun } \\
\text { approximately the same as that for the }\end{array}$} \\
\hline \multicolumn{2}{|c|}{$\begin{array}{l}\text { 17. Key Words (Suggested by Author(s)) } \\
\text { Gears; Surface fatigue life; CBN grinding; Gear life; } \\
\text { Residual stress; AISI } 9310\end{array}$} & \multicolumn{3}{|c|}{$\begin{array}{l}\text { 18. Distribution Statement } \\
\text { Unclassified-Unlimited } \\
\text { Subject Category } 37\end{array}$} \\
\hline $\begin{array}{r}\text { 19. Security Classif. (of this report) } \\
\text { Unclassified }\end{array}$ & $\begin{array}{r}\text { 20. Security Classi } \\
\mathrm{U}\end{array}$ & $\begin{array}{l}\text { of this page) } \\
\text { assified }\end{array}$ & $\begin{array}{c}\text { 21. No of pages } \\
12\end{array}$ & $\begin{array}{l}\text { 22. Price* } \\
\mathrm{AOO} 2\end{array}$ \\
\hline
\end{tabular}

NASA FORM 1626 OCT $86 \quad$ *For sale by the National Technical Information Service, Springfield, Virginia 22161 